\title{
A SHORT HISTORY OF DISEASES COMMON TO HIS MAJESTIES OWN ROYAL REGIMENT OF HORSE GUARDS COMMONLY CALLED THE BLEWES, WHEN ABROAD
}

\author{
MAJ GEN A MACLENNAN, OBE, MB, (Retd)
}

The above is the title of a large MSS book written by John Buchannan. It runs from September 1742 until March 1746, and deals with the medical care of the Blues whilst they were on Active Service in the Low Countries and in Germany during the War of the Austrian Succession. Buchannan was Surgeon to the Blues from 1734-46.

The book, now in the Muniment Room at Millbank, was purchased (from Sotheby's) six years ago and came from the family of de Ros. It gives a quite unique picture of what regimental medical practice was like two hundred and forty years ago. It deserves to be published in toto but space forbids (the typed copy of the MSS runs to over 71 close typed foolscapped pages) and in the following few pages I can merely touch on some of the many points which Buchannan makes in the hope that some of my readers will be stimulated to consult the original.

First a word about the Author. Buchannan appears both in Johnston's Roll and in the Roll of Officers of the Blues (in the Public Record office) as John Bohannan but this must be a clerical error as his name appears as John Buchannan in his MSS book. From internal evidence it would appear that he is a Scottish graduate and that the book was compiled (presumably from contemporary notes) subsequent to April 1758.

The book opens with the departure of the Regiment. "The Regiment embarked at Gravesend Sept 1st 1742 old style in good health without any remarkable accident to man or horse, had a good passage to Ostend being only three days at sea with fair weather; the most part of the officers and men were sen-sick purging and vomiting freely." It is interesting to note that none of the horses were sea-sick. Incidentally Buchannan has a lot to say about the care of the horses and their treatment but space alas forbids more than a brief note.

The Regiment marched to Bruges and so to Ghent where they were accommodated in Barracks.

The first major disease which Buchannan notes is the Itch. This is not surprising as Scabies was one of the most severe scourges of Armies. Indeed it was not until 1867 that the treatment of Balsam of Peru was introduced and itch as a major military disease vanished.

In the mid 18th Century treatment consisted of emetics, purgatives and other means intended to purify the blood; if the surgeon succeeded in curing the patient of the itch in six months he was quite satisfied. In addition to the foregoing Buchannan employed Mercury ointment well rubbed in to the affected parts with good results. He clearly knew that the disease was related to personal cleanliness and observed that "none of the officers had it, and only two of their servants, as they daily attended their masters, were obliged to keep themselves clean".

As might be expected whilst in Ghent with its canals the Blues suffered from the Ague "regular Quotidian". Buchannan found that "it's needless to enquire of 
a more certain remedy than the Simple Barke, if the disease once forms into a regular Ague, I am certain it will cure and never saw it fail".

Buchannan was a man who noted the association of Ague with water and remarks that "the Garrison quartered on the high ground of St. Peter's Hill in Ghent has been less subject to this disease than those who are in the lower part of the town and near the canals". He continues "I have observed the same in England when our Regiment marched into Kent and Essex to escort his Majesty, the further we marched towards marshy ground and the longer we stayed agues were more frequent, and as we returned into Hertfordshire, some cured of themselves especially if the weather were favourable".

He next deals with smallpox. This was a very prevalent disease which he "treated after Sydenham's manner". Apparently there were no deaths from smallpox either among the officers, men and women and children. Pitting was mild. All in all this was not a disease which caused many problems in the Blues.

In the winter of 1742, Buchannan described the various fevers which broke out. One type was particularly virulent since all men died of it - ? Typhus. Jaundice appeared but was not serious and all men recovered.

Consumption again in the mid 18th Century was a common complaint. Again the observant Author notes "Consumptive and phthising people are always better in the field than in Garrison; providing that their duty be moderate".

A very full account is given of Venereal Disease - like the itch a problem for the 18 th Century RMO. Mercury was the great standby but Buchannan is modern with his emphasis on a light diet. There next follows a full description of methods of treatment for ulcers, bruises, dislocations and fractures. There is nothing special to note except the common sense which Buchannan displays.

We now come to what should have been the most interesting part of Buchannan's book viz the treatment of gun shot wounds as the Blues took part in the battle of Dettingen and Fontenoy. He mentions a few cases but remarks "We have many wounded at Fontenoy and such variety of cases that it's impossible to narrate them". He gives some instances of "how some people bear pain better than others" and goes on to the instance "Major Johnston of the Horse Guards received a shot in the left ankle, the bones smashed to pieces and the foot hanging by the great tendon, the large arteria bleeding at full stream. I stitched the artery, cut off the ankle, dressing dry with proper bandage etc., leaving the amputation of the leg to a more convenient opportunity."

This gentleman never changed his voice or altered his countenance. When I told him you must lose your leg he answered coolly, that shall be the work of another day. The like accident happened to General Campbell at Fontenoy: "as I could not get to the blood vessels in order to secure them, was obliged to perform the amputation, and during the operation he asked an exact report of the battle from his Aide de Camp".

In contrast when he amputated the arm of $\mathrm{Cpl}$ Orford the latter "fainted at the beginning of the operation and did not know he had lost his arm till he observed the dressings". Buchannan notes that "our cuirasses saved many lives at Fontenoy".

A sad comment is "The wounded horses would not foresake their Regts, tho they had lost their riders and followed so long as they could walk and some had only three legs to stand on". 
Buchannan was sent to the French camp to visit the English wounded and he had this to say "Their surgeon went round the hospital carrying a tub of brandy and syringes with which they washed the wounds, dressing with dry lint dipt in brandy and covering with digestive. The wounded lay on straw or hay in houses, churches, barns etc. Our men say the French bleed often and cut much".

He also visited the Hanoverian Hospital which was excellent and surprisingly modern. "The Hanoverians had their hospital baggage in the field. Their hospital was soon put up in good order; their men in good houses lay on palliasses stuffed with straw, have good coverings; their dressings are very neat of clean lint; wounds cleaned with fine sponge soaked in warm water and brandy. Their hospital medicines are carried on a large waggon divided into many different partitions and opening at many places; any particular medicine may be easily got at, the whole easily packed and inspected". Shades of our German 1866 Apothecary's Van which used to adorn the Museum!

We have not space to deal with the Flux and other fevers with which the Blues had to contend beyond noting that the bloody flux (dysentery) was often fatal.

An interesting light is shed on conditions in the Army by a remark of Buchannan - "It's surprising what people can do when forced to it: Many tender women and young children marched with us thro' Germany were never on horseback nor carried in waggons. At Windsor Forest camp children of eight years old marched from that camp to Glasgow in one month's time. One of our Trooper's wives in Germany marched 36 hours with the child in her arms the fourth day after delivery".

We take leave of Buchannan and the Blues - "March 2nd old style 1746, we arrived at Gravesend in high spirits and well pleased with seeing Old England".

To conclude then Buchannan shows himself as a skilful, humane and cultured medical officer well worthy to have had the medical care of the Blues.

I would like to express my thanks to Col A V Tennuci, Curator of the RAMC Historical Museum, for his kindness in making a typed copy of Buchannan's MSS available to me.

I would also like to record my thanks to Mr J A Stoneley who typed my MSS. 